\title{
Marginal Teachers from the Eyes of School Principals: Concept, Problems and Management Strategies ${ }^{1}$
}

\author{
Cetin Erdogan ${ }^{1}$, Nihan Demirkasimoglu ${ }^{2}$ \\ ${ }^{1}$ Faculty of Education, Department of Educational Sciences, Yildiz Technical University, Istanbul, Turkey \\ ${ }^{2}$ Faculty of Education, Department of Educational Sciences, Hacettepe University, Ankara, Turkey \\ Correspondence: Dr. Cetin Erdogan, Faculty of Education, Department of Educational Sciences, Yildiz Technical \\ University, Esenler, Istanbul, Turkey.
}

\author{
Received: January 11, 2016 Accepted: January 16, $2016 \quad$ Online Published: January 20, 2016 \\ doi:10.11114/jets.v4i4.1318 URL: http://dx.doi.org/10.11114/jets.v4i4.1318
}

\begin{abstract}
This research aimed to determine how Turkish principals define marginal teachers and which strategies they use to deal with them. Within this purpose, the following points are examined: (a) the concept of marginal teacher, (b) the underlying reasons for marginal teacher behaviors, (c) the problems marginal teachers cause in school settings, (d) the strategies principals use most to deal with marginal teachers, and (e) possible precautions to be taken to deal with marginal teacher behaviors. The study is performed as a qualitative research. The participants in this study are comprised of 18 high school principals from general and vocational high schools from urban and rural regions of Ankara, Turkey. The data required in relation to the aims of the study are gathered through interviews with these principals. The gathered data are analyzed by content analysis method. As can be seen from the findings of the research, school principals defined marginal teachers within three categories. These are; reluctant teachers who do not love their profession but do it due to some economic obligations; incompetent teachers who have weak subject area knowledge and are resistant to professional development and change and difficult teachers who continuously create problems at school due to their personality characteristics or personal problems. The reasons underlying the behaviors of marginally teachers were stated to be teaching profession's gradual loss of status and value, inefficient systems of teacher education and appointment, lack of sanctions imposed in case of poor performance and incompetency and reflection of problems experienced in private life into professional life. Strategies most widely employed by the principals to manage marginal teachers are construction of mutual dialogues, conducting an investigation, overlooking the problem and assigning different tasks to marginal teachers. The most important problems brought about by marginal teachers are deteriorating academic performance of students, their declining interests, attendance and motivation, discontent on the part of parents and negative impacts on other teachers' performance and motivation.
\end{abstract}

Keywords: marginal teachers, incompetent teachers, challenging teachers, poor teaching, principals

\section{Introduction}

One of the most important responsibility areas of principals in school administration is effective management of human resources. In this context, dealing with problematic teachers is a challenging problem for principals, as they cause damage for both students and school environment. Their poor performance consumes much of the principal's time and may damage the school's reputation (Yariv, 2004). In the literature, different types of problematic teachers conceptualized in various terms like "poor performing", "challenging", "incompetent", or "marginal" teachers.

The term of "poor performing", at first glance, evokes incompetence in teaching performance. But Yariv (2004) points out that the concepts of "poor performing" and "incompetence" are linguistically different from each other: while "poor performing" describes the results of an actual behavior, "incompetence" emphasizes skills and personality traits. Besides, Yariv (2004) states that the term 'challenging' often substitutes others such as 'poor performance', 'marginal' or 'problematic'.

The incompetent teacher is defined by Ehrgott and others $(1993,5)$ as "one who lacks the abilities, power and/or fitness

\footnotetext{
1 The results of this research was presented at "The European Conference on Educational Research" on 13-16 September, 2011. Berlin, Germany.
} 
to ever meet the legal qualifications for performing the duties and responsibilities of a classroom teacher". In their research, Wragg et al. (1999) discovered that head teachers and teacher union officers defined incompetent teachers as "having poor class management", "problems with planning and preparation", "lack of differentiation", "inadequate teaching skills such as lack of pace, variety and interest" and "poor relationships with pupils". In a similar vein, according to Tucker (2001) incompetence of teacher refers to "a lack of relevant content knowledge or necessary skills in such key areas as instruction and classroom management".

As for the term "marginal teacher", in the research of Sweeney and Manatt (1984) school principals defined the term as one who appears to have sufficient command of subject matter but who is lack of classroom management skills hinders the student learning. Fuhr (1990) claims that marginal teachers could be categorized into three main types:

Lack of training: Incompetent teachers who doesn't grasp basic teaching techniques,

Personal reasons: Teachers who have serious personal problems for exhibiting chronic inadequacies in classroom management and so slipped back into marginal category and

Poor attitude: Teachers who have negative or poor attitudes about teaching. Teachers in this category know what is expected but refuse to do it.

In a similar manner with Fuhr, Nicolas $(2008,2)$ defined the marginal teacher as "the teacher who is not meeting minimum expectations one or more of the following categories: 1) classroom/behavior management 2) delivery of instructional strategies, or 3) knowledge of content". Kaye (2004, 245-250) classified marginal teachers into the following three groups considering the reactions of school principals:

Flotsam marginal teachers: This group includes novice teachers or teachers who are recently transferred to a new school and who are devoid of professional teaching competencies. These teachers are described as "self-motivated and able neither to improve their teaching or to seek out the assistance they needed to effect change."

Jetsam marginal teachers: This group is comprised of teachers who do not offer their support when a new instructional program requiring some changes to be made in their school is implemented and who are discouraged, unmotivated, and frustrated. These teachers are also running out of their eagerness and energy to teach.

Club Med marginal teachers: These teachers are quite indifferent to students, their learning and teaching profession. They do not care about development and have an unacceptable work ethics and they are viewed to be lazy and indifferent by their colleagues. Such teachers are not cognizant of the fact that they lack teaching competencies; on the contrary, they view themselves as very hardworking teachers.

Many authors (Fuhr, 1990; Ehrgott et al., 1993; Kennedy, 2002; Kaye, 2004) define the marginal teacher as a professional who is not incompetent but wandering very close to the borders of incompetency and needs to improve and with a little support, he/she can achieve this improvement. According to Kennedy (2002), marginal teachers are not the teachers who are hopeless and should be discarded from the profession; rather they are teachers who are exhibiting performance under the ideal level. According to Fuhr (1990), marginal teachers raise their performance enough to be judged 'average' to protect themselves from dismissal in evaluation period but in the following days, they will slip back into their chronic pattern of poor teaching. However, empirical research shows that school administrators see almost no difference between marginal teachers and incompetent teachers and use these two terms interchangeably most of the time (Ehrgott et al., 1993; Myricks, 2009, 109).

In this study, "marginal teacher" is chosen as an umbrella term which covers "incompetent", "poor performing", "problematic" or "challenging" teachers to address teachers persistent in causing some kind of difficulties or troubles in the school that principals have to manage or deal with them. In the related research, marginal teachers are perceived as "uniquely vexing administrative problems" (Ehrgott et al., 1993) or "subtler and consequently more difficult and systemic problems" (Nicolas, 2008).

At this point the question arises: Why these teachers are marginal or incompetent? According to Bridges (1993) there are some external and internal causes of teachers' incompetency. One of the prevalent external causes is inadequate supervision namely, the supervisors are lack of dealing with incompetency and they fail to take corrective actions. On the other hand, teacher's ability or skill deficiencies in the instructional duties such as inadequate knowledge of subject matter, weak intellectual ability and poor judgement are counted among the most prevalent internal causes (Bridges, 1993).

Despite the rate of marginal teachers in schools is relatively little (Ehrgott et al., 1993; Tucker, 2001) they have damages to school environment and students in many ways. In Sweeney and Manatt's $(1984,25)$ research, according to principal observations the marginal teachers appear sufficient on the subject matter but their deficiency in classroom management skills hinders student learning. In this research, principals expressed that "the marginal teacher often butchers a lesson, 
failing to effectively check for understanding, use modeling appropriately, or attend to student motivation". In parallel, Yariv (2004) reports that challenging teachers cause some difficulties or problems in schools such as poor fundamental teaching skills, discipline problems in their classes, low student achievement, low motivation for teaching, aggressive and insensitive behaviors toward students, unable to keep up with new teaching methods, non-acceptance of principal authority and criticizing other teachers. Kaye (2004) found that the most adverse effect of marginal teachers is felt on students' academic and emotional development. In addition to this, due to marginal teachers, parents' complaints may increase, which results in emotional exhaustion of school personnel and their decreasing job satisfaction (Kaye, 2004). Such harms done to school and students by marginal teachers increase the importance of dealing with or management of such teachers.

\subsection{Dealing with Marginal Teachers}

Damaging effects of marginal teachers compel principals to find out useful methods to deal with them. According to Fuhr (1990) one choice is ignoring challenging teachers but ignoring them usually makes their performance worse. The author suggests three strategies for principals to deal with teachers in the marginal category. Firstly, if the problem with the teacher is poor training, principals should provide constructive coaching and good direction for professional growth. Secondly, principals should offer a few vital and genuine words of encouragement, support, respect and affection to the teachers with personal problems. Lastly, the teachers having chronically negative attitude should be talked clearly and specifically about their negative attitudes. But it should be clear that this reprimand is for specific actions or practices in the classroom, not for being a "bad person".

According to Nicolas $(2008,8)$ researchers have arrived at a consensus about the most ethical and effective practices that principals should pursue. The best practices which assume that all marginal teachers were capable of improvement include creating an environment of high expectations, engaging in an accurate performance evaluation, fostering teacher responsibility, offering intensive assistance to teacher and encouraging collaboration among teachers. However, empirical research shows that the strategies used in real life are different from this best practice. Ehrgott et al. (1993) reported that principals admitted that while dealing with marginal teachers, they prefer to resort to simple strategies such as suspension from school or wanting their resignation. Kaye (2004) stated that principals adopt five basic strategies to manage marginal teachers:

Compensatory: Strategies employed to decrease the influence of marginal teachers at school such as the transfer of the teacher to another school, assigning of different tasks within the school and decreasing the size of their classes.

Formative: Strategies to support the change and development of marginal teachers such as informing about and making suggestions for professional development.

Normative: Strategies aiming to gather teachers around a common goal directed towards development or change such as cooperation between teachers, discussions and observations of each other's practices.

Summative: Judgmental strategies such as offer for assistance by the principal or vice principals, principal's guidance for the change and formal evaluation conducted by a supervisor.

Disciplinary: There are two types of it being overt and covert disciplinary applications. An example of explicit disciplinary applications can be the dismissal of the teacher. An example of implicit ones is persuasion for resignation or early retirement.

The teachers stated that compensatory, formative, normative and summative strategies are frequently used and disciplinary strategies are on the other hand rarely used and the most commonly implemented strategy is changing the school of the teacher (Kaye, 2004). Disciplinary strategies are generally implemented on the basis of laws. In legal amendments related to education, teachers' competency standards, criteria, and the sanctions in case of incompetency were determined. For example, in many states of the USA, many reasons were specified for the teachers to be dismissed in case of incompetency, ineffectiveness and low performance. According to Alaska Statutes (Section 14.20.170), a teacher may be dismissed at any time because of incompetency which is defined as "the inability or the unintentional or intentional failure to perform the teacher's customary teaching duties in a satisfactory manner". Tennessee State defined incompetency as "being incapable, lacking adequate power, capacity or ability to carry out the duties and responsibilities of the position" (Tennessee Code, 49-5-501).

In the Turkish education system, the Ministry of National Education specified general competencies and specific subject-area competencies to be possessed by teachers. Whether teachers possess these competencies or not is determined through a central exam that must be taken by the candidates and during their teaching internship, they are evaluated on the basis of their performance and written and oral exams (Basic Law of National Education, 1973, Art. 43, 45). There is no specification of incompetency in the regulations related to the profession of teaching; however, it is stated that some sanctions would be imposed in case of low performance and professional incompetency. When 
disciplinary crimes such as negligence of the duty, intentional failure to perform the requirements of the profession and disobedience to the orders given are committed, punishments such as warning, condemnation, pay cut and suspension of rank raising etc. are given (Public Servants Law, Art. 124-136). According to the Ministry of National Education Law of Teacher Appointment and Transfer (Art. 58), teachers determined to be not doing their duties as required during inspections and investigations due to their incompetency can be appointed to other public posts.

It has been observed that principals prefer more easily applicable strategies to remediation strategies proposed by experts and disciplinary strategies stipulated by laws to manage marginal teachers. According to research, the most important reasons for this are the reluctance of principals to confront with teachers (Yariv, 2004; Nicolas, 2008; Howland, 2014), finding solutions to this problem is considered to be very time-consuming by principals (Ehrgott et al., 1993; Wragg et al., 1999; Nicolas, 2008), fear of doing something against laws on the part of principals (Wragg et al. 1999), job security provided by regulations and arrangements for teachers (Ehrgott et al., 1993; Howland, 2014), protective attitudes of teacher unions (Nicolas, 2008; Feldstein, 2014; Howland, 2014) and lack of effective strategies to deal with marginal teachers on the part of principals (Nicolas, 2008). In many cases, principals and supervisors get into action only when they are obliged to do so by external factors such as family complaints. And in very few cases, legal actions are taken (Yariv, 2004).

According to Bridges (1990), incompetence of tenured teachers rarely causes dismissal of teachers. In the same line, with reference to some empirical research data Tucker (2001) states that while 5-15 percent of teachers in public schools performing at incompetent level, termination rate including resignations, dismissals of tenured teachers and non-renewals of probationary teachers is less than 1 percent. In Turkish education system, which has lastly about 850.000 teachers, there is no dismissal of tenured teachers because of incompetence or poor performance for the last ten years (MoNE, 2015).

In the light of these arguments, the purpose of this study is to determine how Turkish principals define marginal teachers and which strategies they use to deal with them. Within this purpose, a number of questions were addressed including the following:

1. How school principals define "marginal teachers"?

2. What are the underlying reasons for marginal teacher behaviors?

3. What kind of problems do marginal teachers cause in school settings?

4. Which strategies principals use most to deal with marginal teachers?

5. What are the possible precautions to be taken to deal with marginal teacher behaviors?

\section{Method}

The focus of this qualitative research is on how school principals conceptualize the teachers as "marginal" and the strategies they apply to handle the problems with their relationships. Therefore the underpinning research paradigm of this research is interpretivist where the goal is to focus "on how the social world is interpreted by those who involved in it" (Robson, 2011, 24). This qualitative method enabled us to meet the objectives of our study because of its exploratory nature by providing opportunity to scrutinize a social phenomenon in a realistic, holistic and detailed context (Yildirim ve Simsek, 2008, 39).

\subsection{Design}

Phenomenology was selected as qualitative research design since it is described as "an attempt to reveal the essential meaning of human actions" and "comprehension is achieved first of all, by reflecting upon one's experiences (Gabrielian, 1999, 187). As with all phenomenological research, the aim was to investigate the variations in the conceptualizing the term "marginal teacher" phenomenon in educational settings- in this case, underlying reasons, consequences of marginal teacher behaviors and strategies to deal with them.

\subsection{Participants}

In order to find out the conceptualizations related to marginal teachers in different educational settings, we purposefully selected urban and suburban high schools. The participants in the study were comprised of 18 high school principals located in the metropolitan city, Ankara, Turkey. Participants of the study were between 36 to 56 years old. Seniorities of the participants were between 1 to 25 years. Five of the schools were from general schools and 13 of them were from vocational school types with the aim of capturing the variation as much as possible. Five schools were chosen from rural and 13 from urban regions of Ankara. Number of students of schools changes between 170 and 2890.

\subsection{Data Collection and Analysis}

Data collection was achieved through face-to-face semi-structured interviews conducted by two researchers between 
May and June 2011. The interview form developed by researchers based on a detailed literature review and was pilot tested on four school principals. Researchers applied a semi-structured interview form based on the research questions to frame the interviews. Semi-structured interviews also included follow-up questions to deepen and check the meanings generated by participants. Examples of these question were, "what do you mean by that?", "could you give an example?" and "did you mean...?" Follow-up questions encouraged the participants to exemplify the marginal teacher behaviors specifically. Interviews lasted 40-80 minutes, with an average duration of 1 hour, consistent with the methods suggested for interviews (Glesne, 2012, 154).

As Burnard, Gill, Treasure and Chadwick noted (2008) there are two fundamental approaches in analyzing qualitative data: the deductive approach and inductive approach. In the deductive approach, a structure or predetermined framework is used to analyze data whereas the inductive approach involves analyzing data with little or no predetermined theory, or framework and uses the actual data itself to derive the structure of analysis. In this research, a combination of deductive and inductive methods was applied to analyze the data which we judge to be particularly well suited to the present study. Prior to the data coding, the research questions were considered as themes which will be described as the research questions as well. Interviews were transcribed and coded by both interviews and field notes. Two researchers separately analyzed the data and specified the emerging patterns. Researchers discussed the category of responses emerged from two separate content analysis until they reached a consensus. This coding process permitted the researchers to organize the data under five main themes and sub-themes. Additionally, analytical implications were made from principals' views and findings were compared with similar studies from literature which were consistent with the current study (e.g. Bridges, 1990; Fuhr, 1990; TED, 2009; Turer, 2006; Ozoglu, 2010; Akdemir, 2013, Yildirim and Vural, 2014). Data was analyzed through three-phase content analysis procedure. In the first phase, one of the researchers broke the transcripts down into the basic units, namely under the pre-specified themes of this study. In the second phase, emergent categories from the data were coded by two researchers separately. At the last phase of the analysis, the emerging categories were grouped into subthemes. Participants were identified with a code number such as "P1, P2, P3, ...P18" to ensure anonymity. To ensure both internal validity and present the data more strikingly, content analysis was supported with direct quotations using these codes. Quotations from relevant categories were selected among those which emphasize the differences between the opinions related to the specific categories than the commonalities. Additionally, to ensure the internal validity participant test was applied (Yildirim and Simsek, 2008). Data analysis was sent to three of the participants via e-mail to control for the accuracy which participants approved.

\subsection{Limitations}

This study has some limitations. First, the study uses the data employing school principals' opinions related to the marginal teacher behaviors. Thus, it lacks the teachers and students' conceptualizations related to the researched topic. Despite generating an in-depth data, findings of this study could not be generalized to the teachers of Ankara or Turkey. Different data gathering instruments other than interviews are not utilized.

\section{Results}

Five distinct major themes were emerged from the data in line with the pre-determined research questions. A summary of these themes and the main idea underlying these themes were presented in Table 1.

Table 1. Themes and the main ideas underlying themes emerged from the research questions.

\begin{tabular}{|c|c|c|}
\hline & Themes & Main Idea \\
\hline Theme I & Conceptualization of marginal teacher & $\begin{array}{l}\text { "Teachers neglecting their jobs because of frequent } \\
\text { taking time off" } \\
\text { "Teachers coming to class unprepared" }\end{array}$ \\
\hline Theme II & $\begin{array}{l}\text { Underlying reasons for marginal teacher } \\
\text { behaviors }\end{array}$ & $\begin{array}{l}\text { "Teachers' personality traits incongruent with the } \\
\text { teaching profession" }\end{array}$ \\
\hline Theme III & Kind of problems marginal teachers cause & "Causing student academic failure" \\
\hline Subtheme & $\begin{array}{l}\text { Problems with students } \\
\text { Problems with parents }\end{array}$ & $\begin{array}{l}\text { "Causing a negative image about the school and its } \\
\text { quality" }\end{array}$ \\
\hline & Problems v & $\begin{array}{l}\text { "Being a negative model to the other teachers and } \\
\text { demotivate them" }\end{array}$ \\
\hline Theme IV & $\begin{array}{l}\text { pals use most to cope } \\
\text { s }\end{array}$ & $\begin{array}{l}\text { "Communicating teachers personally" } \\
\text { "Taking a legal action against the teacher" }\end{array}$ \\
\hline Theme V & $\begin{array}{l}\text { Possible precautions to be taken to cope with } \\
\text { marginal teacher behaviors }\end{array}$ & $\begin{array}{l}\text { "Students should be selected and trained rigorously } \\
\text { to faculties of education" } \\
\text { "Principals' authorities should be extended" }\end{array}$ \\
\hline
\end{tabular}

\subsection{Theme I: Conceptualization of Marginal Teacher}

This category comes forward with the principals' definitions of marginal teachers who neglect their works without an acceptable reason. In this sense, teachers often asking for permission or getting health report, unprepared, late to the 
courses and communication problems were the common problems took place among the marginal teacher definitions. Principals' opinions related to marginal teacher conceptualizations were presented in Table 2.

Table 2. Principals' opinions related to the concept of marginal teacher

\begin{tabular}{ll}
\hline Themes & $\mathrm{f}$ \\
Marginal teacher; & 5 \\
\hline neglects the work because of frequent health reports or permission & 5 \\
comes to the course unprepared & 4 \\
goes to the classroom always late & 4 \\
does not have the necessary knowledge, skills and competency required to be a teacher & 3 \\
cannot communicate with the students pedagogically & 3 \\
reflects his/her personal problems to the school life & 3 \\
has psychological problems & 3 \\
cannot have a healthy communication with colleagues & 2 \\
does not like his/her profession & 2 \\
does not have dignity of work & 2 \\
carry all sort of problems to the school administration & 2 \\
does not care about the students properly & 2 \\
cannot have a healthy communication with parents & 2 \\
resists against the supervision of the principal & 2 \\
directs students to the private courses for the sake of their own profit & 2 \\
breaks the school rules & 1 \\
avoids from taking & 1 \\
is incompetent in classroom management & 1 \\
is close to criticism & 1 \\
uses low marks to threaten the students & 1 \\
values his/her personal interest above the profession & 1 \\
gossips & 1 \\
lost his/her teaching enthusiasm & \\
\hline
\end{tabular}

Primary focus of this theme was represented with the teachers neglect their duty under the cover of health problems. To illustrate:

P6 - According to the regulation, when a teacher attends an outpatient department of a hospital for four days, his/her additional course fee is not reduced. Thus, a teacher can take four days-off in every month even if he/she is not ill. Thus, the teacher misuses the regulation.

One of the marginal teacher definition focusing on the deficiency of teacher's field knowledge and pedagogical formation may be illustrated through the following quotation:

P1 - We can define especially teachers having poor professional competence as marginal teachers. Lack of teaching formation and competency makes the teacher unhappy. This has some negative reflections on his/her professional performance. When a teacher is not suitable for the profession of teaching in terms of his/her professional knowledge, skills and interests, he/she can be more easily become a marginal teacher. For instance, the personality of teachers who are very nervous and childish is not suitable for the profession of teaching. Therefore, people both having personality characteristics and skills suitable for the profession should be selected.

Another marginal teacher characteristic defined by the same participant highlights the negative behaviors of teacher only with relationships with the students, but nobody else:

P1 - There are teachers about whom students complain. They do not have any problems except for students. But according to students, they are problematic. Students complain about these teachers through the notes they leave in the request box. One of the students wanted me to observe the class of a teacher by means of a note he/she left in the box and I entered the class of this teacher. Then, another note was left in the box next week to request me to enter the class without notice.

A participant makes a comprehensive definition of marginal teachers by stating:

P3 - These are teachers who do not fulfill, pay attention to and neglect their duties expected from them by the principal, laws, regulations and rules and who want to be paid without working.

These comments were complemented by the problem that teachers are lack of intellectual accumulation:

P17 - Our teachers are not intellectuals; they perform their duties like a civil servant. In my opinion, teachers whose actions do not comply with their words, who are not good models and guides are marginal teachers.

Marginal teacher conceptualizations indicated that the principals define teachers "who frequently receive reports 
without having any health problems or want day-off; thus deteriorate the quality of instruction", "who are coming to class without making any preparations, not open to new methods and techniques, do not try to improve themselves", "who come to class late", "who have personal (private, family) problems and reflect these problems on their professional performances", "who continuously experience communication problems with their students and "who have psychological problems" as marginal teachers.

\subsection{Theme II: Underlying Reasons for Marginal Teacher Behaviors}

As Table 3 shows, the reasons that "teacher's personality incongruence with teaching profession" and "dislike of profession" were the most common underlying the teachers' problematic behaviors according to the principals. The other reasons were presented together in Table 3.

Table 3. Underlying reasons for marginal teacher behaviors

\begin{tabular}{lc}
\hline Themes & $\mathrm{f}$ \\
\hline Unsuitable teacher personality for teaching occupation & 8 \\
Not loving her/his job & 4 \\
Seeing teaching as a secondary work & 4 \\
Having family problems & 3 \\
Incompetency in teaching profession & 3 \\
Being close to change and improvement & 3 \\
Having economical problems & 2 \\
Having psychological problems & 2 \\
Lack of job satisfaction & 2 \\
Quality problems of teacher training programmes & 2 \\
The belief that negative behaviors remain unpunished & 1 \\
Difficulties because of living in a faraway place to the school & 1 \\
Having different ideological views other than colleagues and administrators & 1 \\
\hline
\end{tabular}

One participant claims that personal problems of teachers effects their professional life negatively:

P7 - In their private lives, many people experience a lot of serious problems. Some of them divorced and live away from their spouses and children and they are lonely. All these things negatively affect their professional performance. They are afraid of living similar negative experiences in their professional lives. Thus, they have a tendency to misunderstand others' words.

Principals also reported that teaching profession has a lower status so teachers do not value their activities with these words:

P8 - Owing to the low wage, being a teacher is a not of a high status profession. The public view teaching profession as an ordinary job. A teacher is considered to be inferior to a sergeant or a nurse.

Principals also complained about the incompetency of knowledge field of teachers that varies from one university to another one. Teachers were not competent mainly because of the different teaching quality of universities and then teachers' personal indifferences.

P14 - In my opinion, it is primarily due to lack of adequate subject-area knowledge. The qualities of universities vary greatly; while some universities offer quality education, some others give lower quality education. Second, after they have graduated, teacher candidates do not continue their professional development and do not pay enough attention to their professional development. They think that their job is guaranteed.

In sum, the principals stated that the main reasons for some teachers to be considered marginal are "their personalities not being suitable for the profession", "their not loving the profession of teaching", "their having family problems" and "their not following novelties and developments and not being open to change".

\subsection{Theme III: Kind of Problems Marginal Teachers Cause}

This theme may be divided into three subthemes, based on the problems derived from principals' opinions that marginal teachers cause : (a) students, (b) parents, and (c) colleagues, Each subtheme is described further below.

\subsubsection{Problems Marginal Teachers Cause Related to "Students"}

According to principals, marginal teachers cause troubles with their relationships with the students most in schools. The principals' opinions about the problems caused by marginal teachers for students are given in Table 4 together with frequencies. 
Table 4. Opinions related to the Problems caused by marginal teachers related to "students"

\begin{tabular}{lll}
\hline & Problem & $\mathrm{f}$ \\
\hline 1 & Causing academic failure & 9 \\
2 & Affecting students' motivation negatively & 4 \\
3 & Deficiencies in classroom management skills & 3 \\
4 & Reflecting personal problems to the students & 3 \\
5 & Misbehavior towards students & 2 \\
6 & Being indifferent to student's problems in the classroom & 2 \\
7 & Being unable to earn students' respect & 1 \\
8 & Using violence towards students & 1 \\
9 & Giving higher grades to the students than they deserve & 1 \\
10 & Increase in student's absenteeism & 1 \\
11 & Being unable to communicate with students & 1 \\
\hline
\end{tabular}

Two examples for a pessimistic teacher behavior were portrayed as follows:

P8 - The students of a marginal teacher do not like the school, they do not want to study, they do not have self-confidence, they cannot establish healthy communications and they cannot solve problems.

P11 - The teacher who feels helpless in front of students and cannot hide his/her helplessness tends to either resort to violence or threat or higher grades to satisfy students.

Comments on teachers' personal problems underlines its negative reflections to students by depressing them:

P3 - By getting students affected from their personal problems, marginal teachers do some disservice to their students.

P17 - The teacher scorns students and does not believe in them. As the teacher thinks that "No matter what I do, it won't work", he/she cannot help students.

It is evident that such teachers most negatively affect their students' academic achievement and motivation to learn. In addition to this, marginal teachers reflect their problems on their students, treat their students badly, resort to violence and avoid communicating with their students.

\subsubsection{Problems Marginal Teachers Cause Related to "Parents"}

Principals reported that problematic behaviors of teachers affect the parents' attitudes to school negatively by constructing misleading images and causing prejudices. One of the most common problems caused by teachers is parents' complaints about ineffective education and conflicts with parents. The principals' opinions about the problems caused by marginal teachers for parents are given in Table 5 together with frequencies.

Table 5. Opinions related to the problems caused by marginal teachers related to "parents"

\begin{tabular}{lll}
\hline & Problem & f \\
\hline 1 & Causing parents to feel upset because of the incompetent education they get & 5 \\
2 & Causing a negative image about the school and its quality & 3 \\
3 & Conflict in teacher-parent relationships & 2 \\
\hline
\end{tabular}

Principals described many problematic teacher behaviors with such examples:

P1 - Everything, positive or negative, experienced at school finds reflection on the part of parents. Marginal teachers make parents think negatively about the school.

According to principals, marginal teachers do not believe in the capacity of students and school. They do not believe that students can learn and school can teach:

P8 - The marginal teacher thinks that students do not gain anything from attending school, they do not believe in formal education.

In addition, marginal teachers attempt humiliating behaviors with their relationships with parents:

P17 - Some marginal teachers insult, reprimand, humiliate parents; instead of being constructive, they prefer to be destructive.

P3 - Marginal teachers blame parents for the failure of students.

The school principals think that marginal teachers make parents gain negative image of the school, lose their belief in education given in the school and generate prejudices about teachers. Due to marginal teachers, parents think that their children do not get quality education. Parents do not prefer to establish healthy communication with marginal teachers and usually experience conflicts with them. Some teachers; on the other hand, hold parents responsible for the failure of students. 


\subsubsection{Problems Marginal Teachers Cause Related to "Colleagues"}

Our data reveal that marginal teachers display a negative model for the other teachers and attempt to effect their activities negatively or hinder them. The principals' opinions about the problems caused by marginal teachers for other teachers are given in Table 6 together with their frequencies.

Table 6. Opinions related to the Problems caused by marginal teachers related to "colleagues"

\begin{tabular}{lll}
\hline & Problem & f \\
\hline 1 & Demotivating the other teachers through being negative models & 6 \\
2 & Influencing the teachers negatively who are doing well & 3 \\
3 & Causing decrease in cooperation and helping among the teachers & 2 \\
4 & Causing over charge for the teachers doing well & 1 \\
\hline
\end{tabular}

Four principals complained that marginal teachers decrease their colleagues' motivation with these words:

P10 - Marginal teachers try to prevent other teachers from doing their jobs. They create rumors about hardworking teachers like "they are lickspittle of the principal" and try to discourage by saying "You work hard, you might be awarded with a medal".

P13 - When teachers doing voluntary works see marginal teachers, they feel tempted to give up working voluntarily.

P17 - Problematic teachers want to draw others to their side and try to influence them so that they will behave like them.

These comments were supported with another principals' complaints providing an underlying reason to remain inactive in case of problematic behaviors.

P11 - As we do not have the authority, we cannot impose an effective sanction on a teacher coming late. Thus, they go on coming late and display a bad example for other teachers.

Considering the principals' opinions, it seems that marginal teachers affect other teachers badly, ruin their motivation to work and try to make them like themselves. As a result of this, desire to assist to each other and cooperate with each other among teachers decreases.

\subsection{Theme IV: Strategies that Principals Use Most to Cope with Marginal Teachers}

Almost all principals try to communicate with problematic teachers first. In the second order, principals conduct legal inquiry. Strategies that principals developed to cope with marginal teachers' problematic behaviors were presented in Table 7.

Table 7. Opinions related to the strategies that principals use most to cope with marginal teachers

\begin{tabular}{lll}
\hline & Strategies & $\mathrm{f}$ \\
\hline 1 & Communicating with teacher personally & 13 \\
2 & Taking a legal action against the teacher & 6 \\
3 & Keeping up appearances & 2 \\
4 & Forcing the teacher to make a change his/her school & 2 \\
5 & Keeping the teacher away from the classroom & 1 \\
6 & Giving marginal teacher's work to another teacher who does well & 1 \\
7 & Do nothing & 1 \\
8 & Charging different responsibilities & 1 \\
9 & Try to create a sense of belonging to the school & 1 \\
10 & Talking about the problems generally at the meetings & 1 \\
\hline
\end{tabular}

Comments of principals preferring to make a speech could be represented with the following examples:

P4 - I talk to him/her; I explain his/her mistakes and make suggestions to cope with his/her problems. The last thing I resort to is legal procedures.

P8 - We have some effective instruments that we can capitalize on. I try to make use of communication skills.

Another principal noted that he applies the tactics to create a positive organization culture.

P1 - We have lunches together to create a positive school culture. I try to create a sense of belongingness and commitment.

One participant stated that giving responsibilities make this kind of teachers to feel themselves valuable.

P18 - I assign various duties and responsibilities to make them feel valuable and needed.

Principals reported several pressures on themselves when they wanted to interfere the problematic behaviors of teachers. More important some of them complained about being lack of authorization. 
P1 - Once I conducted an investigation to make him feel the existence of discipline and to be protected from parents' complaints. The teacher reacted to it.

P11 - I try to solve the problems by using the authority bestowed to me by the law but it does not work because in such cases, I can be questioned by a supervisor, a deputy advisor or a general principal for my decisions and actions.

P12 - As long as there aren't any serious problems, I try to handle the situation. You cannot dismiss, suspend; you do not have the authority needed to do such things.

Another principal adopting a punitive approach claimed that it worked and the other teacher came aware of the possible outcomes of problematic behaviors.

P13 - We managed to appoint one of the marginal teachers to another place and this worked well. Other marginal teachers realized that they could be expelled from the school.

Another principal admitted that they were incapable of coping with them and punish the hardworking teachers by giving them extra work load:

P2 - As the marginal teacher does not do his/her duties, these duties are assigned to hardworking teachers and thus increase others' workload. Thus, those doing their job well are punished.

It is seen that among the strategies used by the principals to deal with marginal teachers, the most commonly used one is to have face-to-face communication to solve the problem. However, this strategy is selected by the principals as legal procedures do not work and they want to avoid long-term conflicts with teachers. The principals also resort to some other strategies such as conducting an investigation, giving a warning and wanting their transfer to other schools. From the statements of the principals, it is understood that conducting an investigation does not usually work but wanting their appointment to other schools works well to get rid of marginal teachers and to give a warning to other marginal teachers that they could also be sent. Overlooking the problems created by marginal teachers, avoiding direct contact with marginal teachers and assigning the least possible work to marginal teachers are among the strategies used by the principals to avoid problems. Another strategy used to manage marginal teachers is to create a positive culture in the school and help them develop a sense of belongingness.

\subsection{Theme V: Possible Precautions to Be Taken to Cope with Marginal Teacher Behaviors}

The question of "what should be done to cope with this kind of teacher behaviors more effectively" was asked to principals. The responses of principals were put an order in Table 8 considering their frequencies.

Table 8. Suggestions to cope with marginal teacher behaviors

\begin{tabular}{lll}
\hline & Recommendations & $\mathrm{f}$ \\
\hline 1 & Students should be selected and trained rigorously to faculties of education & 10 \\
2 & Principals' authorities should be extended & 5 \\
3 & Teachers should be taken to in-service trainings & 5 \\
4 & Marginal teachers should be appointed to other public services other than teaching & 3 \\
5 & Effective supervision mechanisms should be introduced & 3 \\
6 & School should be governed by a committee like a board of trustees with private sector rules & 3 \\
7 & Teachers rights as an employee and salaries should be improved & 2 \\
8 & Good practices should be shared among school principals & 1 \\
9 & Teacher rehabilitation centers should be established in cities & 1 \\
10 & Teachers dismissal should be easier & 1 \\
11 & School rotation should be implemented to teachers like principals for fixed terms & 1 \\
12 & A good communication should be provided among the school shareholders & 1 \\
13 & Principals and their superiors should be employed with fixed term contracts & 1 \\
14 & Training period of prospective teachers in schools should be extended & 1 \\
15 & Morality and character educations towards teachers should be given more importance & 1 \\
\hline
\end{tabular}

According to our data principals believed that teacher selection and training system is at the heart of solving the problematic teacher behaviors. Principal comments representing the importance of teacher selection process will be illustrated by the following examples:

P11 - While selecting teachers to appoint to teaching posts, the only evaluation tool should not be a written 
exam. The candidates' characteristics such as love for the profession and willingness to make sacrifices should also be taken into consideration.

P17 - More importance should be attached to ethical-moral values in teacher education; pre-service teachers should be imparted with national and spiritual values and trained in such a way as to have a strong character.

Some principals focus on the inspectional process of education and claimed that marginal teachers should be rotated on some different positions other than teaching like clerical works in the Ministry of Education.

P7 - Teachers who cannot meet the required conditions should be eliminated; appointed to other public services.

P8 - Principals' authorities should be increased and healthy control mechanisms should be set at local and national levels.

Similarly, another principal advocates that the intouchable status of teachers as public officers should be terminated and teachers should be employed based on the performance criteria.

P11 - Schools should be directed like private organizations. The responsibility of managing the school should be assigned to a board of trustees. Appointment of the principal and selection of teachers should be under the authority of this board.

P9 - Teachers' performances should be evaluated on the basis of the opinions of students, parents, colleagues and principals and wages should be determined according to these performance evaluations.

Another principal noted that teachers should rotate in specific periods:

P13 - Teachers should not be allowed to work in the same school for long years, their schools should be changed at certain intervals.

A principal also reported that good practices should be shared among the shareholders of Ministry of Education. He suggested:

P1 - Principals should share best practices with each other. For this purpose, the required infrastructure should be established at local and national levels.

The principals think that the tool that can be most conducive to efforts invested to cope with marginal teachers is teacher education system. Therefore, pre-service teachers accepted to education faculties should be selected meticulously, practice should be given greater importance in teacher education and student teachers should learn their job by doing. Moreover, while appointing teachers to teaching posts, the only criterion should not be an exam; other criteria such as personality characteristics, interest in the job should also be taken into consideration.

Another proposal offered by the principals to deal with marginal teachers is to increase the authorities of principals and to manage the school like a private organization. In this regard, principals should be bestowed with greater authority for the recruitment and dismissal of teachers, wages of teachers should be determined according to their performance and teachers should not have life-long job guarantee. Another frequently stated strategy is to rehabilitate marginal teachers through in-service trainings and seminars. There are some other suggestions such as improvement of control mechanisms, facilitation of dismissal and rotation of teachers.

\section{Discussion}

The related literature searches show that the concept of marginal teacher is used with some close terms like "incompetent teachers", "poor performing teachers", "challenging teachers" etc. Accordingly, it comes into question how principals define the term of "marginal teacher" or which problems or deficiencies cause to define a teacher as "marginal".

While defining the concept of marginal teacher, the principals specified which teachers they view as marginal and the reasons for their becoming marginal. The principals' definitions of marginal teachers can be discussed under three groups: reluctant teachers, incompetent teachers and difficult teachers.

In the first group, there are reluctant teachers who do not love their profession but do it as they do not have any other alternative to earn money. The teachers in this group neglect their duties on the ground of health problems or similar problems, are lazy, come to the class without any preparation and late, use every opportunity to skip school and class and are not willing to do their duties. The teachers in this group are in this profession not as they wanted but as they felt obliged.

Due to life-long job guarantee, there is a great deal of interest in recruitment by public sectors in Turkey. The profession of teaching is one of the professions offering the greatest employment opportunities in the public sector. Therefore, even 
those who are not interested in the profession may want to become a teacher due to regular income and job guarantee, though its income is not very high and do not want to leave it unless they have to. As a result of field study conducted in 2009 , it was found that at least one-third of the teachers do not want to do the profession of teaching but they go on doing as they are obliged to (TED, 2009). In addition to this, when compared to other countries and other professions in Turkey, wages of teachers are relatively lower, the recruitment policies are wrong and the whole education program is centrally managed and thus the teacher does not have professional autonomy; all these negative conditions lead to continuous deterioration of the social status of the profession (Ozoglu, 2010). This has negative influences on job satisfaction and increases the number of reluctant teachers.

In the second group, there are "incompetent teachers" who have poor subject-area knowledge and are resistant to professional development and change. Though these teachers are professionally incompetent, they do not invest any efforts aimed to professional development, prefer to stay away from training opportunities provided for professional development and they perform their duties with minimum performance and effort. Not going beyond the limited methods and techniques for instruction, these teachers avoid learning new methods and techniques and generally show resistance to calls coming from school administration in this direction. These specifications given for these teachers are similar to the specifications proposed by Kaye (2004) for jetsam and club med marginal teachers.

The indifference of teachers in professional development is also noted in the literature. According to the results of a study looking at teaching competencies in Turkey, the ratio of the teachers not having participated in any in-service training in the last 2 years is $40 \%$, the ratio of those following any journals on educational sciences or their own subject-area is $12 \%$, the ratio of those having not read any book for professional development in the last one year is $14 \%$ and the ratio of those having read one or two books is 47\% (TED, 2009).

The principals think that the reason for this is that there is no sanction imposed in case of poor performance or incompetency and the inefficient systems of teacher education and selection. In the Turkish education system, guidance and control are two problematic areas. Due to institutional control and investigations, supervisors have heavy workload; thus, they cannot spare enough time for the control and guidance of teachers. According to the regulations related to the duties of supervisors (MoNE, 2014), it is not an obligation for supervisors to evaluate classroom performance of teachers and they mostly leave this work to principals. However, research shows that principals are inefficient in the control and guidance of teachers (Ekinci, 2010); spend most of their time on financial issues of the school and their daily routine duties (Zoraloglu, Sahin and Firat, 2004; Aslanargun and Bozkurt, 2012). Thus, teachers are left without supervision and they are not confronted with any sanctions in case of poor performance and incompetency. According to the information officially requested from the Ministry of National Education for the current study, no teacher has been suspended from his/her work for the last 10 years.

Inefficient teacher training and appointment processes are viewed to be another important reason for the incompetency of teachers. The task of teacher training in Turkish education system was carried out by the Ministry of National Education up to 1982, then it was assigned as the responsibility of education faculties. However, education faculties lack adequate and qualified faculty members; many of the academicians working at education faculties are coming from disciplines not related to education; some academicians are not familiar with the practical aspects of the profession of teaching and there are some problems associated with the infrastructure and equipments in these faculties. Due to such problems, the desired education cannot be given to pre-service teachers at education faculties (YOK, 2007; Ozoglu, 2010).

Another source of problems is the inability to establish a consistent teacher appointment system for years and frequent amendments made to the teacher appointment system. For instance, in 1990s, in order to meet the need for classroom teachers, pre-service teachers from different branches were appointed as classroom teachers; even worse, graduates of disciplines such as agricultural engineering and business administration were also appointed as classroom teachers and then they received their formation while they were active teachers (Turer, 2006). Similar applications are still continuing under the name of formation education and graduates of other faculties can be appointed as teachers after completing a 10-course pedagogical formation program at education faculties. Such applications increase the workload of education faculties and result in deterioration of their quality of education (Azar, 2011) and are severely criticized as they do great disservice to teacher training efforts in general (Yildirim and Vural, 2014). A study conducted in 2009 revealed that $21.7 \%$ of the teachers work in branches different from what they are educated for (TED, 2009); this is the result of wrong teacher training policies. Moreover, at schools suffering from the shortage of teachers, graduates of faculties other than education faculties are recruited as contract teachers. All these applications exacerbate the problem of incompetent teachers.

In the third group, there are "difficult teachers" who experience difficulties in communicating with people due to their personality characteristics and/or personal problems. They experience communication problems sometimes with their 
colleagues or administrators or sometimes with students and their parents. Teachers experiencing communication problems with their colleagues are unsuccessful in establishing positive relationships with their colleagues, cannot get along with them and might be reluctant for cooperation and assistance. Teachers experiencing communication problems with their students are those who do not care about students, are not interested in and sensitive to them and sometimes use grades as a means of threat. Teachers experiencing communication problems with parents usually do not want to involve parents in educational process and avoid communicating and cooperating with parents.

According to the principals, one of the basic reasons for the incompatibility and communication problems of teachers is their having personality characteristics not complying with the requirements of the profession of teaching. In this connection, lack of an effective appointment system having the capacity of selecting candidates with personality characteristics suitable for the profession of teaching is severely criticized. Candidate teachers are appointed as teachers according to their scores taken from an exam centrally implemented at national level. No other criteria such as interest in the profession, personality characteristics, communication skills are taken into consideration. These shortcomings are among the problems noted in the literature (Baskan, Aydın and Madden, 2006; Akdemir, 2013). In addition, lack of effective remediation services to help "difficult teachers" to improve their weaknesses leaves these problems unsettled. The place, time and content of in-service training programs offered to teachers are centrally determined by the Ministry of National Education; thus, they cannot provide insights into the solutions to problems experienced at school level (Ozoglu, 2010). When teachers cannot cope with the problems they experience in their private life, family life and relationships, they can reflect these problems on their professional life and this is another source of important problems for school.

Though some teachers included in the group of "difficult teachers" experience some psychological and neurological problems, they go on doing their work and they cannot demonstrate a good performance. Teachers exhibiting some syndromes of neurological disorders such as Alzheimer, schizophrenia and panic attack somehow get the approval from medical organizations that they could go on working, which results in serious problems in the provision of educational services.

The marginal teachers included in the above-mentioned categories cause many problems for school. According to the principals, marginal teachers who are incompetent in their field and doing their job reluctantly do the greatest harm to the academic achievement of students. It is clear that the contribution of teachers having poor academic abilities to their students will be very small. In this context, Baker and Dickerson (2006) reported positive correlation between academic abilities of teachers and their students' outcomes. In addition to this, marginal teachers negatively affect their students' interest in school and classes, motivation to learn and attendance. Teachers experiencing communication problems and psychological problems tend to give higher grades to their students, sometime demonstrate negative attitudes towards their students and even resort to violence. These problems created by marginal teachers result in discontent of parents with the school and their complaints about the school and the teacher. Marginal teachers sometimes establish negative relationships with parents and might clash with them.

Another problem caused by marginal teachers at school is that other teachers might be adversely affected by them. Other teachers witnessing that though they neglect their duties and cause many problems, marginal teachers are not exposed to any serious sanctions might lose their interest and motivation. Furthermore, marginal teachers adversely affect other teachers with their words and criticisms.

The principals experience great difficulties in dealing with marginal teachers. The most popular strategy adopted by the principals to deal with marginal teachers is to establish a dialogue followed by conducting an investigation, overlooking the problem, assigning the marginal teacher to other duties. When they cannot solve the problem through dialogue, they might decide to use their legal rights and demand an investigation to be conducted for the teacher. However, as the investigation process is a long process and laws are quite protective for teachers, it is seen to be an ineffective process for the solution of problems by the principals. Thus, the principals think that they should be given more authority to impose sanctions on marginal teachers. As a result, problems caused by marginal teachers are sometimes overlooked and sometimes left untouched. Some teachers on the other hand prefer to assign some other duties for marginal teachers or get other teachers to do the duties of marginal teachers.

Another remarkable finding of the current study is that the principals do not resort to remediation processes. It seems to be clear that face-to-face dialogues will not work to solve the problems with marginal teachers. Besides, the principals desire more authority and this may indicate that they tend to solve the problems experienced with marginal teachers through legal means. The findings show that there is no systematic treatment adopted to deal with marginal teachers and they are usually left to their own devices. However, in the literature, there are some systematic approaches proposed to deal with marginal teachers. Range, Hewitt \& Young (2014) conducted a study on elementary school and high school principals in America and they were asked to explain the approach they adopted to deal with marginal teachers. The 
most commonly adopted approaches were found to be "build a systematic case for improvement" and "take a position depending on the teacher. In addition to these, some other approaches were also stated such as "convince improvement to avoid dismissal" and "place pressure to improve" and "avoidance of confrontation with the teacher" were found to be the least preferred approaches. Myricks (2009) proposes an example application in which the marginal teacher is assigned to another position/duty. In this connection, a marginal teacher having 37-year teaching experience but having problems in class was assigned as Early Intervention Program teacher and there the teacher became more successful.

Principals made some suggestions to deal with the problems brought about by marginal teachers. First of these suggestions is the establishment of more effective teacher training system. In Turkey, university entrance exam is centrally held. The principals think that apart from the university entrance exam, some other criteria considering the skills and personality characteristics required by the profession of teaching should be applied for the selection of students to education faculties. Moreover, while educating students at education faculties, they should be made more aware of the requirements of the profession and subjected to intense moral training. Other suggestions include strategies such as using in-service training programs and rehabilitation programs to deal with the problems of marginal teachers.

The suggestions of the principal coincide with the suggestions made by the research conducted on teacher training in Turkey to a great extent. The suggestions made in the literature on teacher training include reconstructing the teacher training system through a scientific and an innovative approach, putting more emphasis on practice in teacher training programs, conducting exams to evaluate the suitability of candidates' personality characteristics and competencies for the profession while appointing them (Baskan, Aydın and Madden, 2006; Akdemir, 2013), establishing an effective cooperation and coordination between the Ministry of National Education, the Council of Higher Education and education faculties to train better teachers, making in-service training programs more widespread and more qualified, encouraging teachers for professional development (Ozoglu, 2010; Akdemir, 2013).

Complaining about the ineffectiveness of the sanctions that can be used to manage marginal teachers, the principals want more effective sanctions. To do so, many principals believe that public schools should be managed like private schools, which is believed to make teachers more hardworking and careful. Moreover, increasing the authority of principals, more effective use of inspections, facilitation of dismissal of marginal teachers or assigning them to other public services are among the suggestions made by the principals. The underlying reason of these suggestions is that when principals are unable to solve problems with face-to-face dialogues, they prefer conducting an investigation or discharge the teacher instead of using effective remediation strategies.

In conclusion, even though the rate of marginal teachers in schools is relatively little, they may cause a signifficant negative effect to the school environment. For this reason, school principals shouldn't ignore the marginal teacher problem. By means of in-service education and training processes, principals should be enabled some skills of using effective remediation strategies for marginal teachers. Thus, it may be possible to improve, instead of dismissal, marginal teachers on borders of incompetency.

\section{References}

Akdemir, A. S. (2013). Türkiye'de öğretmen yetiştirme programlarının tarihçesi ve sorunları [A History of Teacher Training Programmes and Their Problems In Turkey]. Turkish Studies: International periodical for the languages, literature and history of Turkish or Turkic, 8(12), 15-28.

Alaska, S. (2015). Retrieved from http://codes.lp.findlaw.com/akstatutes/14/14.20./02./14.20.170 on 20.03.2015

Aslanargun, E., \& Bozkurt, S. (2012). Okul Müdürlerinin Okul Yönetiminde Karşılaşıtı̆ı Sorunlar [Problems That Principals Face in School Administration]. Gaziantep University Journal of Social Sciences, 11(2), 349-368.

Azar, A. (2011). Türkiye'deki Öğretmen Eğitimi Üzerine Bir Söylem: Nitelik mi, Nicelik mi? [Quality or Quantity: A Statement for Teacher Training in Turkey] Journal of Higher Education and Science, 1(1), 36-38. http://dx.doi.org/10.5961/jhes.2011.004

Baker, B. D., \& Dickerson, J. L. (2006). Charter schools, teacher labor market deregulation, and teacher quality: Evidence from the schools and staffing survey. Educational Policy, 20(5), 752-778. http://dx.doi.org/10.1177/0895904805284118

Baskan, G. A., Aydın, A., \& Madden, T. (2006). Türkiye'deki öğretmen yetiştirme sistemine karşılaştırmalı bir bakış [A Comparative Perspective of Teacher Training System in Turkey]. Çukurova University Journal of Social Sciences, 15(1), 35-42.

Bridges, E. M. (1990). Managing the Incompetent Teacher. Retrieved from ERIC \#ED320195.

Bridges, E. M. (1993). The Incompetent Teacher: Managerial Responses (A Revised and Extended Edition). Bristol: Taylor\&Francis Inc. 
Ehrgott, R., Henderson-Sparks, J., \& Sparks, R. (1993). A Study of the Marginal Teacher in California. Paper presented at the Annual Meeting of the California Educational Research Association, November 1992, San Francisco, CA. Retrieved from ERIC \#ED356556.

Ekinci, A. (2010). Aday Öğretmenlerin İş Başında Yetiştirilmesinde Okul Müdürlerinin Rolü [Roles of Headmasters on the Job-Training of the Pre-Service Teachers]. Dicle University Ziya Gökalp Journal of Education Faculty, 15, 63-77.

Feldstein, M. (2014). How to achieve stronger U. S. growth. Journal of Policy Modeling, 36(2014), 649-653. http://dx.doi.org/10.1016/j.jpolmod.2014.03.007

Fuhr, D. (1990). Supervising the marginal teacher. Here's How, 9(2).

Gabrielian, V. (1999). Qualitative Research Methods: An Overview. In G. J. Miller \& M.L. Whicker (Eds)., Handbook of Research Methods in Public Administration. New York: Marcel Dekker (pp.167-223).

Gill, P., Stewart, K., Treasure, E., \& Chadwick, B. (2008). Methods of data collection in qualitative research. British Dental Journal, 204(6), 291-295. http://dx.doi.org/10.1038/bdj.2008.192

Glesne, C. (2012). Nitel Araştırmaya Giriş [An Introducion to Qualitative Research] (Edt: Ali Ersoy, Pelin Yalçınoğlu). Ankara: Anı Publications.

Howland, J. (2014). The decision-making processes of principals when recommending marginal teachers for tenure. Doctoral Dissertation. The Graduate School of Education. Rutgers-The State University of New Jersey.

Kaye, E. B. (2004). Turning the tide on marginal teaching. Journal of Curriculum and Supervision, 19(3), 234-258.

Kennedy, J. (2002). Developing intuition in marginal trainees on teaching practice. ELTD, 7, 44-53.

MoNE. (2014). MEB Rehberlik ve Denetim Başkanlığı ile Maarif Müfettişleri Başkanlıkları Yönetmeliği [Regulation of MoNE Guidance and Supervision and Educational Supervisors'Directory]. Resmi Gazete [Official Gazette]. Publication Date: 24/05/2014. Number: 29009.

MoNE. (2015). 20/03/2015 date and 892643 numbered response to knowledge acquisition application.

Myricks, N. B. (2009) Principals' perceptions: The use of formative evaluations to assist marginal teachers. Doctoral Dissertation. Tift College of Education. Mercer University. Atlanta, GA.

Nicolas, R. L. (2008). Middle and High School Principal responses to marginal teachers in Kentucky Districts of varying size. Doctoral Dissertation. Faculty of College of Education, Spalding University, Luisville, KY.

Ozoglu, M. (2010). Türkiye'de Öğretmen Yetiştirme Sisteminin Sorunları [Problems of Teacher Training System in Turkey]. SETA Analiz. No: 17.

Public Servants Law. (1965). Resmi Gazete [Official Gazette]. Publication Date: 23/07/1965. Number: 12056.

Range, B., Hewitt, P., \& Young, S. (2014). Principals' perceived supervisory behaviors regarding marginal teachers in two states. Administrative Issues Journal:Education Practice and Research, 4(1), 62-73. http://dx.doi.org/10.5929/2014.4.1.7

Robson, C. (2011). Real World Research (3rd ed). Oxford: Blackwell.

Sweeney, J., \& Manatt, D. (1984). A team approach to supervising the marginal teacher, Educational Leadership, 1984-April, 25-27.

TED. (2009). Öğretmen yeterlikleri [Teachers' Competencies]. Ankara: Türk Eğitim Derneği.

Tennessee Code, 49-5-501. http://law.justia.com/codes/tennessee/2010/title-49/chapter-5/part-5/49-5-501(13.05.2015)

Tucker, P. (2001). Helping struggling teachers, Educational Leadership, 2001 February. 52-55.

Turer, (2006).Türkiye'de öğretmen yetiştirme ve sorunlar [Teacher Training and Problems in Turkey]. Abece Journal, March-April 2006, 235-236.

Wrag, E. C., Haynes, G. S., Wragg, C. M., \& Chamberlin, R. P. (1999). Managing Incompetent Teachers. Paper presented at the Annual Meeting of the American Educational Research Association (Montreal, Quebec, Canada, 19-23 Nisan 1999).

Yariv, E. (2004). 'Challenging' teachers: What difficulties do they pose for their principals? Educational Management Administration \& Leadership, 32, 149-169. http://dx.doi.org/10.1177/1741143204041881

Yildirim, İ., \& Vural, Ö. F. (2014). Problems related with teacher training and pedagogical formation in Turkey. Journal of Teacher Education and Educators, 3(1). 73-90. 
YOK. (2007). Türkiye’nin yüksekögrrenim stratejisi [Higher Education Strategy of Turkey]. Ankara.

Zoraloglu, Y. R., Sahin, İ., \& Fırat, N. Ş. (2004). İlköğretim Okullarının Finansal Kaynak Bulmada Karşılaştıkları Güçlükler ve Bu Güçlüklerin Okula Etkileri [Difficulties that Primary Schools Face in Finding Financial Source and Its Impact on Schools]. Education, Science and Society, 2(8), 4-17.

This work is licensed under a Creative Commons Attribution 3.0 License. 